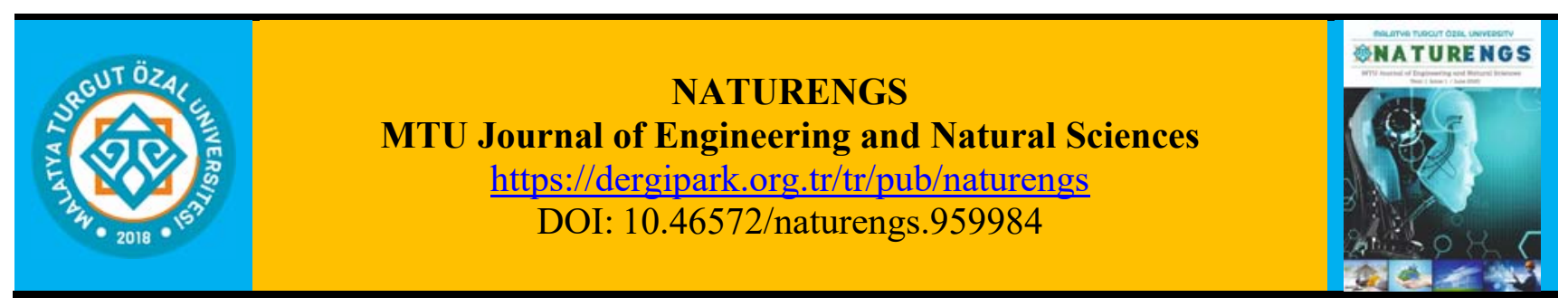

\title{
The Thermal and Mechanical Properties of the Building Stones in Eskisehir - Kayseri and Kursehir regions
}

\author{
Ayşe Biçer \\ Department of BioEngineering, Faculty of Engineering and Natural Sciences, Malatya Turgut Özal University, \\ Malatya, Turkey.
}

(Received: 30.06 .2021 ; Accepted: 05.11.2021)

\begin{abstract}
In this study, certain physical properties of Derbent (Eskisehir), Tomarza (Kayseri) and Mucur (Kırsehir) stones, which are used as building materials in the relevant regions, are subjected to analysis. For each stone, the samples were taken from two separate quarries, after which the chemical analysis, thermal conductivity, compression stress, water absorption, breathability and abrasion tests were carried out. The results obtained from the tests carried out are as follows: $i$ ) It is understood that Eskisehir Derbent tuff and Tomarza stones can be used as briquettes, bricks or aggregates as lightweight concrete thanks to their low thermal conductivity values $(0.355 \mathrm{~W} / \mathrm{mK}$ and $0.581 \mathrm{~W} / \mathrm{mK})$ and heat insulation properties. ii) Kırșehir Mucur stone shows that it can be used in load-bearing wall material and abrasion-resistant flooring with $88.46 \mathrm{MPa}$ compressive strength and $0.4 \%$ volume abrasion values. iii) It has also been conferred that three stones have rich reserves and low costs. The results are compared with other building materials, especially in terms of energy-saving, strength and comfort conditions.
\end{abstract}

Keywords: Derbent tuff, Mucur stone, Tomarza stone, Building material.

\section{INTRODUCTION}

Natural stones are mineral assemblages formed by the combination of one or more minerals. A stone can be composed of a single mineral or a combination of several minerals. Calcite, Dolomite, Quartz, Orthose, Plagioclase, Biotite-Muscovite, Hornblende, Pyroxene-Olivine are some of the important minerals found in the combination of stones.

Natural stones have been utilized by humankind since the beginning of civilization up to date. The largest historical buildings that survive to date were made of stone. Typical examples include Egyptian Pyramids, Greek Acropolises, Roman Amphitheaters, Ottoman fountains and mosques, Artemis Temple and Halicarnassus Mausoleum. Additionally, roads, bridges, squares, monuments and obelisks are also other structures where natural stones are widely used [1]. The structures in question were built with stones brought from hundreds of kilometers away, as the result of years of effort.

Turkey is one of the richest countries in natural stone presence, while also having a great potential in terms of both reserve and diversity aspects. Today, stones are used in a wide range of areas such as road and paving, curbstone, wall material, coastal fortification, breakwater, dam construction and aggregate production. Stones maintain their importance in today's modern building industry [1]. Stones obtained from the quarries gain functionality by cutting in place, exploiting natural discontinuities and using explosives. The use of natural stones as building

*Corresponding Author: ayse.bicer@ozal.edu.tr

ORCID number of authors: 0000 -0003-4514-5644 
and decoration materials has led to an increase in natural stone production across the world. Today, as a result of both the price increases in construction materials and the increase in housing demand, the use of natural stones as a carrier and filling element, depending on the geological structure of each region, is brought to the agenda.

Some studies on building blocks have been carried out in the literature in this area. Some of these studies are summarized as follows:

In the study they carried out, Taşligil and Sahin have investigated the determination of the characteristics and geographic distribution of wealth comprehensively along with the detection of natural stone used as building materials in Turkey [1]. Pivko conducted researches on the formation of Stones [2]. Gevrek \& Kazanci ignimbrite formation [3]; Kazanci \& Gurbuz [4], the geological formation of the natural stone of Turkey. Dinçer et al. conducted a study on the water absorption rates of ignimbrites [5], while Bakiş et al. carried out a study on the use of Ahlat Stone in the construction sector [6] and Bicer conducted a study determining the thermal and mechanical properties of Ahlat and Malazgirt Stones [7]. In a different study, Bicer investigated the thermal and mechanical properties of building blocks used as building construction materials in many regions of the Euphrates basin [8]. Similarly, in another study carried out by Biçer, the physical properties of the building stones used in buildings in the Elazı $\breve{g}$ and Nevşehir regions were determined accordingly [9]. Doran and Kaygisiz, in their dissertations on an individual basis, investigated the formation of Erciyes volcanism, the physicomechanical properties of the tuff and building stones from the eructation $[10,11]$. Demir investigated the building blocks found in Kırşehir and its vicinity [12], and Çavumirza et al investigated the physicomechanical properties of Mucur stone [13]. Daloğlu \& Emir investigated certain properties of Derbent tuff, as one of the building stones found in Eskişehir [14].

For these natural stones to be used as building materials in the best manner possible, all physicomechanical properties are required to be well known. In this study, Tomarza stone (Kayseri), Mucur stone (Kırşehir) and Derbent Tuff (Eskişehir), which are used extensively in the relevant regions, were examined and certain properties of the same were subjected to analysis. Stones have been preferred by the local people and used in old buildings up to date. This study sets forth the reasons for preference with the properties determined as a result of the tests carried out on the stones.

\section{MATERIAL AND METHODS}

\subsection{Materials}

\section{Eskisehir Derbent Tuff:}

It is quarried in blocks within the cut stone quarry located near Derbent Farm village, approximately $20 \mathrm{~km}$ southeast of Eskişehir. Compared to artificially produced counterparts, there is no product cost other than a cutting process in the quarry. It has been used as the most important material and building element in masonry buildings for many years. Derbent tuff has acidic magma characteristics and is a type of rock resistant to heat due to the minerals it contains. It also provides thermal insulation due to the porous structure of tuff. There are several examples of Ottoman architecture in which tuff was used as cut stone in Anatolia as can be seen in the recent past. Eskişehir Kurşunlu Complex, which was built in 1525 in connection with the same, is one of the structures that has survived to date (Figure 1). Today, it is produced and used as cut stone, especially in Kayseri and Nevşehir provinces. There are two separate cut 
stone quarries in Derbent Farm in Eskişehir. While there is no production process carried out in the quarry that produces pink tuff, the quarry for white tuff continues its production process $[14,15]$.

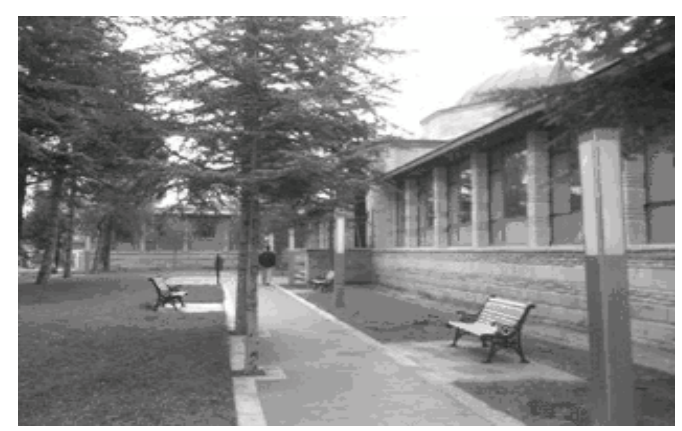

Figure 1. Kursunlu complex [14]

\section{Kayseri Tomarza Stone:}

These are the tuff stones that are the ignimbrite of Erciyes Mountain, as the largest extinct volcano in Central Anatolia. The stone samples were obtained from natural stone quarries located in Tomarza District of Kayseri Province. It can be used as wall cladding, floor and stair flooring, road and pavement flooring, and it is frequently preferred to be used in structures such as fountains, fireplaces, barbecues and tombstones [11]. Because the colors of these stones are attractive, they are also used for decoration purposes, as well. The colors available are Dried Rose, Yellow, Tomarza Black, Brown, Antique Yellow colors (Figure 2). The properties of the stones can be summarized as follows: color, pattern, appearance, hardness, durability, resistance to external factors and ability to be cut and polished. Tomarza Stone can be used as a building block due to its ease of processing after being quarried, along with its ability to gain strength as long as it stays under atmospheric conditions. In addition, Tomarza Stone is especially preferred for decorative purposes due to its wide variety of colors, its ability to be polished on the surface and its aesthetic appearance.

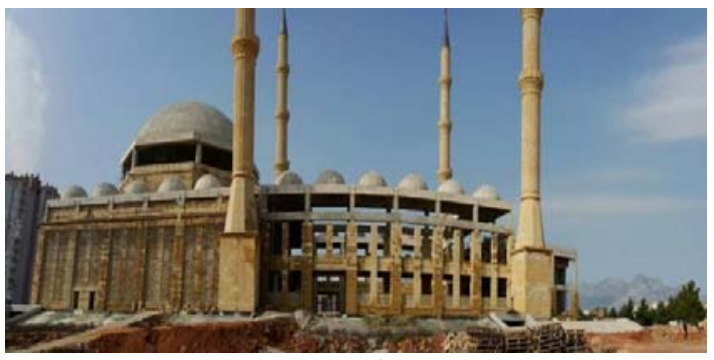

a)

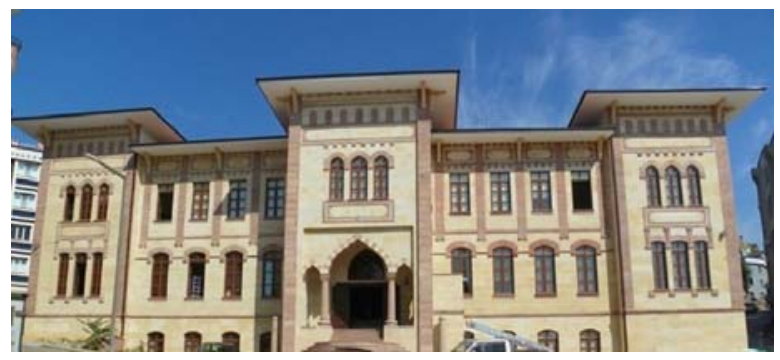

b)

Figure 2. a) Akdeniz University Mosque (Tomarza yellow), b) Biga Government House (Dried rose and antique yellow) [10] 


\section{Kırsehir Mucur Stone:}

The stone samples were obtained from the crushed stone production quarry located in the northeast of Kırşehir Province, within the boundaries of İnaç village at the 7th km of KırşehirMucur highway. The chemical contents of the limestone marbles taken from the surface in the study area were determined accordingly and shown in Table 1. The stones are used as aggregate in the production of quality concrete in the region with a first-degree seismic zone [13]. Due to the roughness of crushed aggregate surfaces, it creates a strong adherence between cement paste and aggregate. The larger the rough surface is, the larger the contact surface of crushed aggregate and cement paste becomes. For this reason, it can be seen that the strength properties of concretes produced with crushed stone aggregate have improved accordingly.

Table 1. The chemical composition of the samples, (\%)

\begin{tabular}{|c|c|c|c|c|c|c|c|c|}
\hline $\begin{array}{l}\text { Component } \\
\text { Material }\end{array}$ & $\mathrm{SiO}_{2}$ & $\mathrm{Al}_{2} \mathrm{O}_{3}$ & $\mathrm{Fe}_{2} \mathrm{O}_{3}$ & $\mathrm{CaO}$ & MgO & $\mathrm{K}_{2} \mathrm{O}$ & $\begin{array}{l}\text { Loss of } \\
\text { ignition }\end{array}$ & Undefined \\
\hline Derbent stone & 68.9 & 12.11 & 1.19 & 1.03 & 2.91 & 4.66 & 5.72 & 3.60 \\
\hline Tomarza stone & 61.88 & 15.95 & 1.82 & 6.38 & 3.18 & 1.22 & 7.13 & 2.51 \\
\hline Mucur stone & 0.36 & 0.012 & 0.09 & 54.73 & 0.40 & 5.19 & 36.4 & 2.88 \\
\hline
\end{tabular}

\subsection{Methods}

The samples of 150x60x20 mm for thermal tests and 100x100x100 mm for pressure and wear tests were prepared from the stones taken from the quarries and subjected to the following tests (Figure 3).

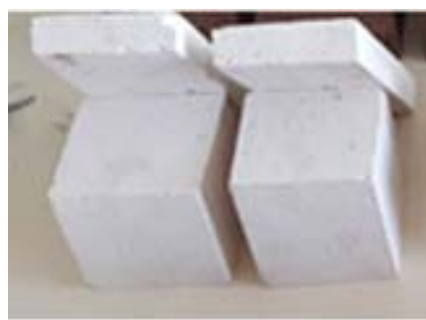

a)

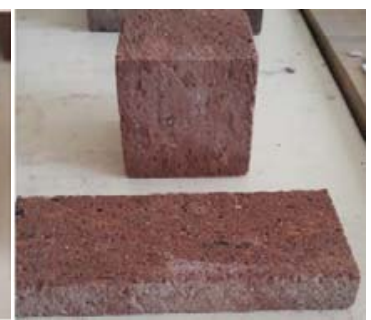

b)

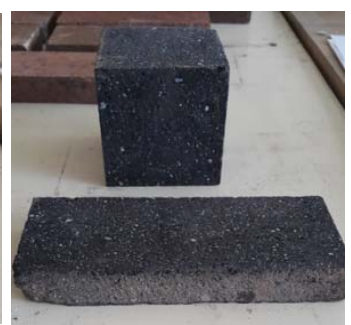

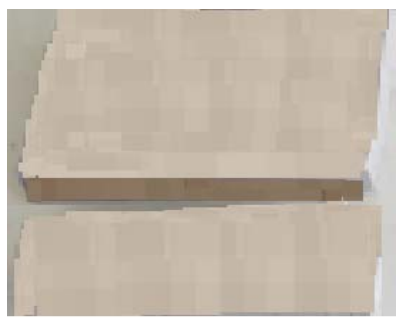

c)

Figure 3. Color samples of natural building stones a) Derbent tuff, b)Tomarza stone, c) Mucur stone

\subsubsection{Thermal conductivity}

The measurement procedures were carried out with "Shotherm-QTM", measuring in the temporary regime and operating in hot-wire method (Fig. 4). Measuring as per DIN 510406 norm, this device was used to carry out measurements from 3 different points on every sample under room temperature of 22$25^{\circ} \mathrm{C}$, calculating the arithmetic mean of these 3 values. The thermal conductivity coefficient of the device has a tolerance of $5 \%$ between 0.02 to $6 \mathrm{~W} / \mathrm{mK}[16,17]$. Measurement results are given in Table 2. 


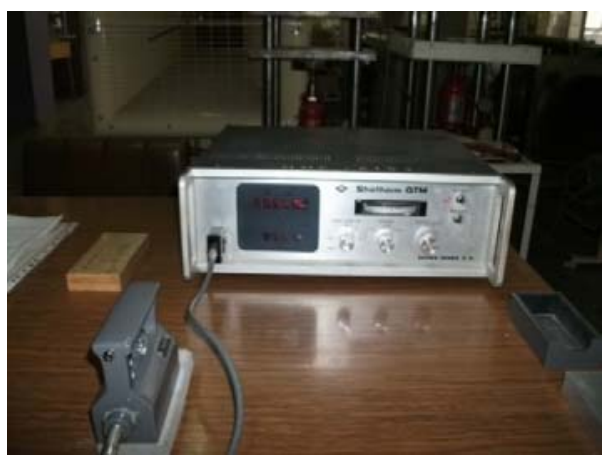

Figure 4. Shotherm-QTM unit

\subsubsection{Compressive strength and abrasion tests}

Endurance tests were carried out on the samples following TS 699 standard [18]. Compressive strength tests for the samples were carried out with Ele International branded device, bearing the following features: $3000 \mathrm{kN}$ loading capacity; digital control panel; adjustable loading rate; applying uniaxial force.

Volume abrasion lost results for $88 \mathrm{rpm}$ within the scope of frictional abrasion tests can be seen in Table 3.

\subsubsection{Water absorption test}

The objective of this test is to determine the presence of a dry volume, where the ice crystals within can expand, as the building materials -in direct contact with water- freeze [19]. This feature ensures a warranty for the material against freezing. The dry weight $\left(\mathrm{W}_{\mathrm{k}}\right)$ of each sample was determined. Then the water level is gradually raised within the water tank, where the samples are placed, adding water into the tank in a manner allowing the samples to be submerged. The change of the samples' weight based on time can be seen in Figure 3. After keeping the samples in the water for 48 hours, they were removed out of the water and wiped, finding the water-absorbed weight $\left(\mathrm{W}_{\mathrm{d}}\right)$, while on the other hand calculating the water absorption ratio with the Eq. 1.

Water absorption percent $=\left\{\left[\mathrm{W}_{\mathrm{d}}-\mathrm{W}_{\mathrm{k}}\right] / \mathrm{W}_{\mathrm{k}}\right\} \times 100$

\subsubsection{Density test}

Dry weights of the samples were taken with the weighing machine having a tolerance of $1 \%$, while the density levels were calculated by identifying the sample volumes.

\section{RESULTS AND DISCUSSION}

The following findings were obtained in this study conducted to investigate the thermal and mechanical properties of some stones, which are used in the center and districts of Kayseri, Kurşehir and Eskişehir provinces located in the Central Anatolia Region, as well as having large reserves. 


\section{Eskisehir-Derbent Tuff:}

Tuff is a natural building stone and is produced as cut stone. Derbent tuffs do not meet the requirements to be used as flooring and outer covering stone with $17.17 \%$ volume abrasion and $30.44 \%$ water absorption ratios (Table 2, Figure 5). Since tuff is a lightweight and easily processable material, it can be produced by being sliced on site. Therefore, according to their artificially produced counterparts, tuffs do not have any costs other than the cutting process in the quarry. Derbent tuff has similar properties with pumice concrete, concrete briquette/concrete block and less-hole brick, which is used as an artificial filling wall material and is a more cost-friendly alternative product. The lightness of tuffs compared to natural filling wall materials increases the resistance of the building against earthquakes as it reduces the dynamic loads on the structure in high-rise buildings.

Derbent tuff looks better than concrete, granite, marble, limestone and sandstone with its thermal conductivity coefficient of $0.355 \mathrm{~W} / \mathrm{mK}$. For this reason, it will provide heat and sound insulation where it is used as a filling material in brick, briquette and walls in buildings. Additionally, considering the compressive strength value of $11.39 \mathrm{MPa}$, it has approximately equivalent strength with artificial materials such as briquette, brick, aerated concrete although it is lower than high strength natural building stones.

\section{Kayseri Tomarza Stone:}

Tomarza Stone is included in the class of light building materials, while it greatly reduces the dead load of the buildings, such as Derbent tuff, and reduces energy costs by contributing to the thermal insulation of the buildings thanks to the closed pores in its internal structure. Tomarza Stone can be used both as a building stone and as a covering stone thanks to its high compressive strength compared to tuff-class rocks. The fact that the buildings in the Tomarza Region, where the climatic conditions are very heavy in winter, still maintain their durability is an indicator of the resistance of the stone to atmospheric conditions. Due to its high color variety and aesthetics, Tomarza Stone is preferred for decorative purposes, as well. The low water absorption rate indicates that it can be used as exterior cladding.

With its $0.581 \mathrm{~W} / \mathrm{mK}$ thermal conductivity value, Tomarza stone seems to be better compared to the building materials given in Table 4. Additionally, considering the compressive strength of $22.58 \mathrm{MPa}$, it has approximately equivalent strength with artificial materials such as concrete, briquette, brick, aerated concrete although it is lower than high strength building blocks. Notwithstanding that it can be used as a wall covering material with a $5.8 \%$ abrasion loss, it can also be seen that it cannot be used as a building element subject to excessive wear such as stairs, parquet.

\section{Kırşehir Mucur Stone:}

Kırşehir Mucur Stone seems to bear better properties compared to granite, sandstone and marble with thermal conductivity of $1.483 \mathrm{~W} / \mathrm{mK}$. Its compressive strength and abrasion values appear to be more durable than other stones examined. The fact that the water absorption rate is less than $30 \%$ indicates that the stones can be used in humid environments.

Examining the drying rates seen in Figure 6, it can be seen that the three regional stones examined have respiration capability, albeit it is low. 
Table 2. Thermal and mechanical properties of stones

\begin{tabular}{lccccc}
\hline \multicolumn{1}{c}{ Materials } & $\begin{array}{c}\text { Density } \\
\left(\mathbf{k g} / \mathbf{m}^{\mathbf{3}}\right)\end{array}$ & $\begin{array}{c}\text { Thermal } \\
\text { conductivity } \\
(\mathbf{W} / \mathbf{m K})\end{array}$ & $\begin{array}{c}\text { Compressive } \\
\text { strength } \\
(\mathbf{M P a})\end{array}$ & $\begin{array}{c}\text { Water } \\
\text { absorption } \\
(\mathbf{\%})\end{array}$ & $\begin{array}{c}\text { Volume } \\
\text { abrasion } \\
(\%)\end{array}$ \\
\hline Derbent tuff & 1420 & 0.355 & 11.39 & 30.44 & 17.17 \\
Tomarza stone & 1740 & 0.581 & 22.58 & 17.09 & 5.18 \\
Mucur stone & 2720 & 1.483 & 88.46 & 10.13 & 0.4 \\
\hline
\end{tabular}

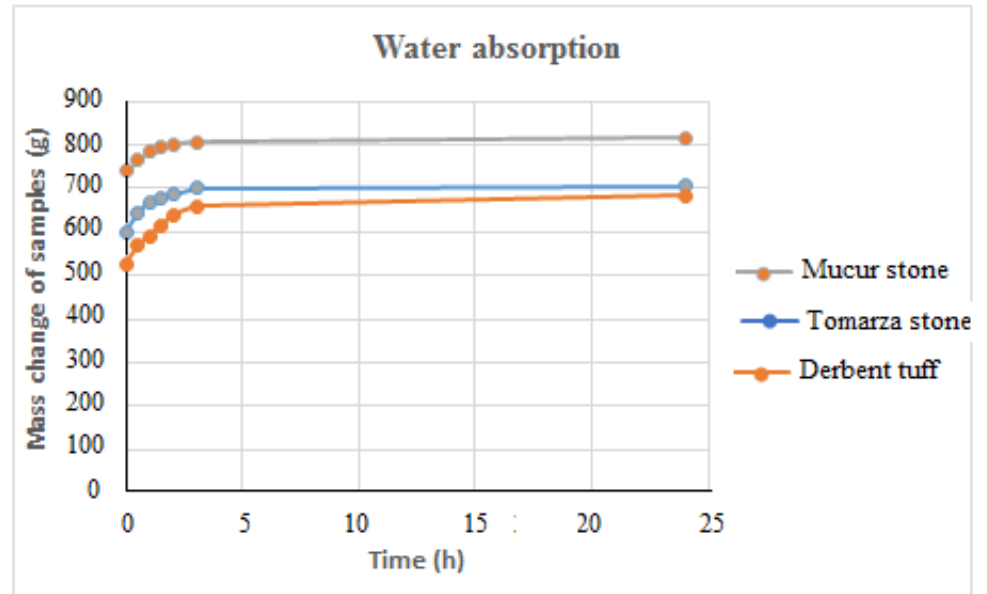

Figure 5. Mass change of stones according to time in water absorption test

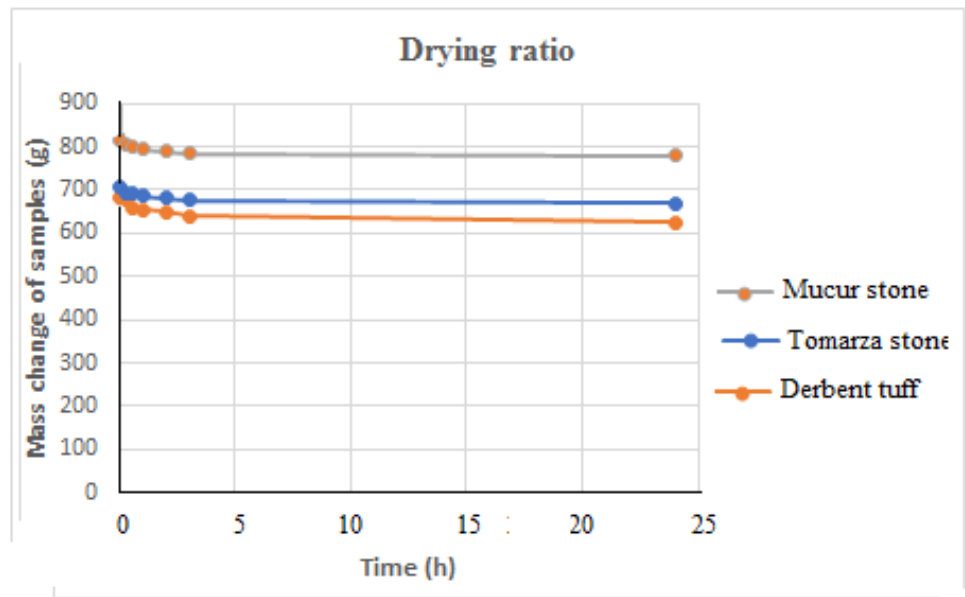

Figure 6. Mass change of stones according to time in drying test

Table 3. The physical properties of some building materials [20]

\begin{tabular}{cccc}
\hline Materials & $\begin{array}{c}\text { Density } \\
\left(\mathbf{k g} / \mathbf{m}^{\mathbf{3}}\right)\end{array}$ & $\begin{array}{c}\text { Thermal } \\
\text { conductivity } \\
\text { (W/mK) }\end{array}$ & $\begin{array}{c}\text { Compressive } \\
\text { strength } \\
\text { (MPa) }\end{array}$ \\
\hline Concrete & 1906 & 0.814 & 20 \\
Granite & 2643 & 1.73 & 120 \\
Limestone & 2483 & 1.16 & 35 \\
Sandstone & 2235 & 1.85 & 80 \\
Marble & 2603 & 2.77 & 50 \\
Common & 1602 & 0.692 & 16 \\
brick & 1602 & & \\
\hline
\end{tabular}




\section{CONCLUSIONS}

The thermal and mechanical properties of the local stones used as construction elements in the center and districts of Kayseri, Kırşehir and Eskişehir provinces were experimentally subjected to examination, and the results obtained are given as follows:

Eskişehir Derbent tuff can be used as a filling material in low-density concrete, briquette, brick making due to its lightweight $\left(1420 \mathrm{~kg} / \mathrm{m}^{3}\right)$ and its low thermal conductivity coefficient $(0.355 \mathrm{~W} / \mathrm{mK})$. If it is used for this purpose, the heating costs of the building will decrease and also the dynamic loads on the building in high-rise buildings will decrease, and it will increase the resistance of the building against earthquakes. The high rate of water absorption indicates that it cannot be used as a building siding material.

With its low density and thermal conductivity $\left(1740 \mathrm{~kg} / \mathrm{m}^{3}\right.$ and $\left.0.581 \mathrm{~W} / \mathrm{mK}\right)$, using Kayseri Tomarza stone instead of bricks on the outer walls of the building is advantageous in terms of the energy economy. Additionally, it can be used in load-bearing wall structures with its compressive strength value of $22.58 \mathrm{MPa}$ and as an exterior wall covering material with a $17.09 \%$ water absorption ratio value. The fact that the stone is easy to process once it is quarried, and the variety of colors, along with the ability to be polished on its surface increase the appeal of using the stone.

Kırşehir Mucur stone is a stone with a high thermal conductivity value $(1.483 \mathrm{~W} / \mathrm{mK})$ among the stones examined, and no significant value has been conferred within the scope of the thermal properties of the same. On the other hand, the compressive stress of $88.46 \mathrm{MPa}$ shows that it can be used in load-bearing wall material and abrasion-resistant flooring with a $0.4 \%$ wear rate.

Along with the properties of the stones subjected to examination, the fact that the quarry reserves are rich, easy to supply, they can be cut and used directly and their cost is low can be considered as significant reasons for preference, based on these advantages.

\section{REFERENCES}

[1] Taşlıgil, N., and Şahin, G. (2016). Yapı malzemesi olarak kullanılan Türkiye doğal taşlarının iktisadi coğrafya odağında analizi, Marmara Coğrafya Dergisi, 33: 607-640.

[2] Pivko, D. (2003). Natural stones in earth's history, Acta Geologica, 58: 73-86.

[3] Gevrek, A.İ. and Kazanc1, N. (1991). İgnimbrit: oluşumu ve özellikleri, Jeoloji Mühendisliği Dergisi, 38: 3942.

[4] Kazanc1, N., and Gürbüz, A. (2014). Jeolojik miras nitelikli Türkiye doğal taşları, Türkiye Jeoloji Bülteni. 57: 1-6.

[5] Dinçer, İ., Özvan, A., Akın, M., Tapan, M. and Oyan, V. (2012). İgnimbiritlerin kapiler su emme potansiyellerinin değerlendirilmesi: Ahlat Taşı örneği, Yüzüncü Yll Üniversitesi Fen Bilimleri Enstitüsü Dergisi, 17(2): 64-71.

[6] Bakış, A., Işık, E., Hattatoğlu, F. and Akıllı, A. (2014). Jeolojik miras nitelikli Ahlat Taşı'nın inşaat sektöründe kullanımı, III. Uluslararası Ahlat-Avrasya Bilim, Kültür ve Sanat Sempozyumu Bildiriler Kitabı (Editörler Doğru M. ve Aksoy E.), 46-59, 22-24 Eylül Ahlat- Bitlis. 
[7] Bicer A. (2019). Ahlat ve Malazgirt yapı taşlarının bazı fiziksel özellikleri, Fırat Üniversitesi Müh. Bil. Dergisi, 31(2): 301-307.

[8] Bicer, A. (2019). Some physical properties of the building stones from southeastern Anatolia region, Bartin University International Journal of Natural and Applied Sciences, 2(1): 9-15.

[9] Bicer, A. (2019). Some physical properties of the building stones from Elazıg-Nevsehir region, Nevşehir Bilim ve Teknoloji Dergisi, 8(2): 96-102.

[10] Duran, F. (2009). Erciyes Volkanizmasının Oluşumu, Koçcağız Köyü (Kayseri) Dolayının Stratigrafisi ve Tüflerin Yapı-Kaplama Taşı Olarak kullanılabilirliği. Çukurova Üniversitesi, Fen Bilimleri Enstitüsü, Yüksek Lisans Tezi, Adana.

[11] Kaygısız, H. (2010). Kayseri Yöresindeki Yapıtaşlarının Fiziko-Mekanik Özelliklerinin Belirlenmesi. Çukurova Üniversitesi, Fen Bilimleri Enstitüsü, Yüksek Lisans Tezi, Adana.

[12] Demir, I. (2005). The usage properties of Kırşehir regional rocks as crushed stone aggregate, Journal of Polytechnic, 8(1): 111-121.

[13] Çavumirza, M., Kılıç Ö., and Anıl M. (2003). Mucur (Kırşehir) yöresi kireçtaşı mermerleri ve travertenlerinin fiziko-mekanik özellikleri, Türkiye IV. Mermer Sempozyumu (Mersem'2003) bildiriler kitabı 18-19 Aralık 2003.

[14] Daloğlu, G., and Emir, E. (2010). The assessment of tuffs located at Eskisehir-Derbent region as the natural building stone, Journal of Engineering and Architecture Faculty of Eskişehir Osmangazi University, Vol: XXIII, No:1.

[15] Devecioglu, A.G. (2001). An investigation on the heat conduction parameters of porous building stones, Master Thesis, Firat University.

[16] Vysniauskas, V.V, and Zikas, A.A. (1988). Determination of the thermal conductivity of ceramics by the Hot-Wire Technique, Heat Transfer Soviet Research, 20(1): 137-142.

[17] Denko, S. (1990). Shotherm Operation Manual No 125-2. K.K. Instrument products department, 13-9, Shiba Daimon, Tokyo, 105, Japan.

[18] TS 699, (1978). The test and experiment methods of natural building stones, TSE, Ankara.

[19] Bicer, A. (2019). Influence of tragacanth resin on the thermal and mechanical properties of fly ash-cement composites, Journal of Adhesion Science and Technology, 33(10): 1019-1032.

[20] Toksoy, M. (1988). Thermal conductivity coefficients of industrial materials, Journal of Engineers and Machinery, 347: 12-15. 